\title{
The Views of Science Pre-service Teachers about the Usage of Basic Information Technologies (BIT) in Education and Instruction
}

\author{
Oğuz Çetin \\ Correspondence: Oğuz Çetin, Niğde University, Faculty of Education, Department of Computer Education and \\ Instructional Technology, 51245, Niğde, Turkey.
}

Received: June 1, 2016 Accepted: June 15, $2016 \quad$ Online Published: June 29, 2016

doi:10.11114/jets.v4i9.1652

URL: http://dx.doi.org/10.11114/jets.v4i9.1652

\begin{abstract}
In this study aiming to present a description based on science pre-service teachers' views related to use of Basic Information Technologies (BIT) in education and training, an interview is carried out with 21 pre-service science teachers who study in different classes in Faculty of Education, Niğde University. For this aim, improved interview form is used with literature review, the experts of researchers and the views of other experts related to the area. The data acquired with interview form including four sub-dimensions in the way "Computer Aided Education (CAE)", "Hypermedia Use", "Distance Education (DE)" and "Database Management", are solved with content analysis method. As a result of research, it is determined that pre-service teachers generally have fund of knowledge also in body of literature in terms of educational and training dimension. The other works performed practically that will present use cases of BIT of pre-service science teachers in the process of education and training in the way to support this work indicating the current situation, are suggested.
\end{abstract}

Keywords: basic information technologies, science education, pre-service teachers, teacher training, technology

\section{Introduction}

In this age, where technology is developing rapidly, a new community perception showed up named as information society. Information society states a society based on basic information technology (BIT). In information society where BIT is used effectively and reaching the information is simple job from now on, education systems have their own share from this rapid change and development. In terms of BIT, raising well-supported individuals is among the primary aims of education system. At the same time, as a result of the relationship between education and technology, concepts such as educational technology, instructional technology and instruction-technology integration are frequently used by educators.

It is contemplated that in information society, having the adequacy of technology of teachers will directly influence the quality of education. Teacher's knowledge, skill, value and manner related to BIT are shaped with the education they took in teacher training. Teachers will also reach the level of selecting their training materials which they will use in their classes with the education they took before they began teaching. Relevant material selection for the course objectives affects student's level of understanding the lesson and the retention of information (Alkan, 1995; Collier, Paula \& Goff, 1971; Fisher, 2000).

According to Yeung, Tay, Hui, Lin, and Low (2014), digital technology is drawn great interest in educational environments, plays an important role in worldwide modern education, is emphasized in the documents related to many education policies (for example; Department of Education USA, 2010; Ministry of Education New Zealand, 2006-07). A similar situation is observed also in the documents related to the education policies in Turkey. For example, computer and technology literacy was placed in curriculums of all disciplines, using information technologies actively determined as a basic skill needed to be upskilled to elementary and middle school students. It is especially aimed to upskill information technologies in the Science Curriculum. One of the most important factors to upskill using skills of information technologies to basic education students is to train a good teacher in this area. This situation is related directly to teachers' knowing the pre-service information technology, their high understanding and application levels.

The fact that the lectures are intensely based on technology integration, will provide that pre-service teachers graduate as equipped in use of technology (Erdemir, Bakırcı \& Eyduran, 2009). However in researches conducted, they are emphasized that most of teachers and pre-service teachers did not magnificently get ready for technology integration in 
instruction; integration is a boring and time wasting process (A. Arslan, 2006; Board, 2002; Christensen, 2002; UNSPECIFIED, 2001; Levin, 1996; Ruggiero \& Mong, 2013) (as cited in Erdemir et al., 2009). For instance, in a research conducted by Roggiero and Mong (2013), it was made out that although pre-service teachers had compulsory technology education, they had trouble in integrating the technology to instruction practices and programs for teacher education could not completely prepare pre-service teachers with regard to technological proficiency. On the other hand, a similar research conducted by Kim, Kim, Lee, Spector, and DeMeester (2013), it was made out that there is a direct association between technology integration and teachers' perceptions related to technology, and changes in teachers' perceptions will ease teachers' usage of technology.

When the curriculums for teacher education are handled, it is seen that proficiencies related to technology integration and usage of BIT are aimed to be brought with lessons of "Computer I", "Computer II" and even partly "Instructional Technologies and Material Design" in all disciplines as compulsory lesson to pre-service teachers (HEC (Higher Education Council), 2007a). On the other hand, in some faculties of education, contents related to technology integration and usage of BIT are presented to pre-service teachers within elective courses. This situation is same as undergraduate program of Science Teaching, too.

Pre-service teachers of science education especially within the computer courses and Instructional Technologies and Material Design Course in pedagogical field; have learned such contents like basic concepts related with Computer Aided Education (CAE), elements, theoretical foundations, benefits and limits, applying methods, evaluation and selection of course software, distance education application with the database application, the place and importance of teaching technology in process of teaching (HEC, 2007b).

In numerous studies done oppose to that (Anderson \& Maninger, 2007; Arıkan, 2006; Başaran, 2005; Chen, 2010; Erdemir et al., 2009; Güven, 2014; A. Kaya \& Kaya, 2014; Ruggiero \& Mong, 2013; Sadi et al., 2008; Yeung et al., 2014; Y1lmaz, 2007) it is concerned that insufficiency of license programs of teacher training, in terms of computer and technology literacy or is asserted that it must be focused on more courses requiring BIT in programs.

According to Anderson and Maninger (2007) the ultimate aim of computer and technology courses is to be able to create the ability of teaching of pre-service teachers in an effective way in their classes and their willingness. It is so important determining factors related with teacher's using of BIT as teaching aimed in that situation. In education-teaching process to keep up with the fast development of technology in general but in private, teaching staffs and candidates of teacher using BIT must follow these changes closely (Sadi et al., 2008). Ergo it is necessary to find out views and present level of information of candidates of the teacher about BIT who will use BIT for the aim of supporting teaching and improve the ability of computer-technology using of students. The main aim of this study is to observe the views of candidates of teacher about the using of BIT in education and technology.

\section{Method}

\subsection{Research Model}

In this study structured interview which is one of the quantitative research methods was used to determine views of pre-service science teachers about using BIT in education and training. According to Ekiz (2003), structured interview is a quantitative research method that looks like the survey studies or attitude scales, since the participant answers his/her knowledge in various categories. The researcher asks the same questions with same words to the all participants. Within this context, in study with asking questions to science education pre-service teachers about using of BIT in education and training, learning and defining their thoughts and feelings in a systematic manner purpose was aimed. In this way, experiences of pre-service teachers about using BIT in education and training and how they make sense of this was tried to understand (Türnüklü, 2000).

\subsection{The Research Group}

The sampling in the study -regardless of quantity- was designed as non-probability (purposive) with the purpose of getting more in-depth information (Büyüköztürk, Çakmak Kılıç, Akgün, Karadeniz, \& Demirel, 2011). At this point, the research group consists of 21 pre-service teachers who received education in different classes at Niğde University, Faculty of Education, Department of Primary Education, and Department of Science Teaching in the 2014-2015 Academic Year. As the interview questions to be addressed to the pre-service teachers involved the questions associated with the utilisation in the education of BIT, criterion sampling technique was used in the selection of research group. The research group is preferred from the pre-service teachers who took Computer I and Computer II courses which involved the topics of BIT in undergraduate education. With the maximum variation sampling method, the participants were designated from the pre-service teachers who had different grade point average and who completed these courses in different grade levels. Some of the demographic distributions of the pre-service teachers in the research group who were described by coding from S1 to S21 were presented in Table 1. 
Table 1. Some Demographical Qualities of the Research Group

\begin{tabular}{llll}
\hline Feature & & $\mathrm{n}$ & $\%$ \\
\hline \multirow{2}{*}{ Gender } & Female (S2, S3, S4, S5, S6, S7, S8, S10, S11, S12, S15, S17, S18) & 13 & 61,9 \\
& Male (S1, S9, S13, S14, S16, S19, S20, S21) & 8 & 38,1 \\
Class Level $^{1}$ & 2nd grade (S2, S3, S5, S9, S10, S11, S15, S16) & 8 & 38,1 \\
& 3rd grade (S4, S7, S8, S12, S13, S14, S17) & 7 & 33,3 \\
Academic Success & 4th grade (S1, S6, S18, S19, S20, S21) & 6 & 28,6 \\
(100 Points $\quad$ Grading & 80-100 (S1, S2, S3, S4, S5, S6, S7) & 7 & 33,3 \\
system) & 41-80 (S8, S9, S10, S11) & 4 & 19,1 \\
Total & 40 and below (S17, S20, S21) & 7 & 33,3 \\
\hline
\end{tabular}

\subsection{Data Collection and Analysis}

The information on pre-service teachers serving as the participants of the study was obtained from the registrar's office of the faculty to provide the aforementioned characteristics. The data were collected via the interview form developed by the researcher. The development of the interview form was based on the related studies in the literature (Anderson \& Maninger, 2007; Başaran, 2005; Funkhouser \& Mouza, 2013; Karaa, Aydın, Bahar, \& Yılmaz, 2014; Manik, Qasim, \& Shareef, 2014; Önal \& Çetin, 2014; Rodriguez, 1996; Ruggiero \& Mong, 2013; Sadi et al., 2008; Teo \& Noyes, 2014), course contents of Computer I and Computer II, the researcher's previous experience, and the views of other experts of the field. As the concepts of validity and reliability (Türnüklü, 2001), were used during the interviews in relation to the researcher, it was ensured that the same questions were directed to the participants during the interviews using the same words and in the same way.

Interview data were analysed via data analysis, data presentation and data validation approaches (Miles \& Huberman, 1994; as cited in Türnüklü, 2001). Data are divided into subcategories according to determined data coding categories. Each sub-category has been reassembled in accordance with their characteristics; by paying attention to patterns and themes valid conclusions were obtained from given data. During this process contrasts, comparisons and similarities were taken into consideration. Coding procedure was repeated at various time intervals (Türnüklü, 2000; Yıldırım \& Şimşek, 2008). Pre-service teachers' views which were surveyed in basis of interview questions were described within determined general categories, the percentages of interpreted views in basis of sub-categories are expressed numerically. For this purpose, four basic categories are determined. These categories are "Computer Aided Education (CAE)", "Hypermedia Use", "Distance Education (DE)" and "Database Management". These general categories also include subcategories for each.

\section{Results}

\subsection{The Views about CAE}

At the beginning of the research pre-service teachers were asked for examples that can be classified as CAE and cannot be classified as CAE. The derived findings are presented in Table 2 with their frequencies and percentages.

Table 2. Usage Examples Considered as CAE or Not

\begin{tabular}{|c|c|c|c|c|c|}
\hline As CAE & $\mathrm{f}$ & $\%$ & Not CAE & $\mathrm{f}$ & $\%$ \\
\hline Presenting subjects via slide & 9 & 42.9 & Prepared PowerPoint presentations & 13 & 61.9 \\
\hline $\begin{array}{l}\text { Lesson softwares (simulation, } \\
\text { Educational games, instructive programmes, etc.) }\end{array}$ & 8 & 38.1 & Interactive board & 3 & 14.3 \\
\hline Displaying an experiment through computer & 2 & 9.5 & $\begin{array}{l}\text { Reading a lesson book via slides } \\
\text { environment }\end{array}$ & 3 & 14.3 \\
\hline FATIH Project ${ }^{2}$ & 2 & 9.5 & Face to face education & 2 & 9.5 \\
\hline Subject telling CD's & 2 & 9.5 & Teacher's reciprocal ask-answer approach & 1 & 4.8 \\
\hline E-books, tablets & 1 & 4.8 & Traditional education methods & 1 & 4.8 \\
\hline Hypermedia, multimedia & 1 & 4.8 & Using computer only for presentation & 1 & 4.8 \\
\hline Website of Nigde University & 1 & 4.8 & Using computers in offices & 1 & 4.8 \\
\hline $\begin{array}{l}\text { It needs to be a strategy, method, and technics in } \\
\text { order to be CAE }\end{array}$ & 1 & 4.8 & Playing online games & 1 & 4.8 \\
\hline
\end{tabular}

\footnotetext{
${ }^{1}$ As Pre-service Science Teachers took Computer I and Computer II courses in the curriculum of $2^{\text {nd }}$ grade, sampling was not taken from the first grade.

2"'Movement of Enhancing Opportunities and Improving Technology", known as FATIH, is among the most significant educational investments of Turkey. FATIH Project proposes that "Smart Class" project is put into practice in all schools around Turkey. With this project, 42.000 schools and 570.000 classes will be equipped with the latest information technologies and will be transformed into computerized classes (Smart Class).
} 
As is known, CAE refers programmed teaching and puts an emphasis on systematic learning process. But when analyzing Table 2, \%42.9 of pre-service teachers express that "presenting subjects via slide" may be named as CAE. Except this, it is quite interesting that there are also examples which are not accepted as CAE such as "displaying an experiment through computer" (\%9.5) "FATIH Project" (\%9.5), "Website of Niğde University".

Participant S3 expresses her view about CAE: "CD's lecturing are not included in Computer Aided Education (CAE), prepared PowerPoint presentation does not belong to CAE's content but belongs to computer based learning content." S8 expresses that "to set an example as CAE, from Niğde University Website, when entering to page, different pages are opened and these pages are supported with pictures and etc. This may be CAE. To give an example for the ones which are not CAE; the projection of our presentation on the board is not a CAE." S14 expresses: "If a teacher just opens slide presentation and reads to students, this is not appropriate for CAE. However, if teacher explains the subject in detail which is expressed with just one or two sentences and concretizes an abstract subject by the help of animations and videos and if she/he provides integrity then this is appropriate for CAE."

As part of this question, only eight participants (\%38.1) in research emphasized common formats used in CAE. Only one participant opined that there must be strategy, technique and method for CAE. However, these views do not emerge as views that exactly reflect the CAE. For example, S19 opines, "Only watching video or telling an issue, is not CAE. It becomes CAE if it is told according to the level of student with smart board and projector, and supported with picture and video, later it is made as ask-question technique like educational games." Even though the examples of practice, would not be qualified as CAE, are stated correctly by teacher applicants, views, would be stated as CAE, show that they do not have whole knowledge about how CAE corresponds to a learning process.

As part of another question in research, participants were asked to examine the benefits of CAE in terms of students and teachers. The views of the participants are given according to be most pronounced rates with frequency and percentage in Table 3.

Table 3. Pre-Service Teachers' Views on Benefits of CAE in terms of Students and Teachers

\begin{tabular}{|c|c|c|c|c|c|}
\hline To Students & $\mathrm{f}$ & $\%$ & To Teachers & $\mathrm{f}$ & $\%$ \\
\hline It enables easier understanding as it addresses. & 8 & 38.1 & $\begin{array}{l}\text { Via visual, sound-video elements, it is more than } \\
\text { one sense organ more effective in objectify } \\
\text { abstract concepts. }\end{array}$ & 11 & 52.4 \\
\hline It gives opportunity to repeat. & 6 & 28.6 & $\begin{array}{l}\text { Dangerous experiments can be shown on } \\
\text { computer environment. }\end{array}$ & 9 & 42,9 \\
\hline The student is more students oriented. & 4 & 19 & Teachers save up from time. & 5 & 23.8 \\
\hline It increases student's motivation. & 4 & 19 & $\begin{array}{l}\text { Teachers can perform their lesson more } \\
\text { comfortably. }\end{array}$ & 4 & 19 \\
\hline $\begin{array}{l}\text { Students follow the subject according to their } \\
\text { personal speed }\end{array}$ & 3 & 14.3 & It is more effective in getting students' attention. & 3 & 14.3 \\
\hline $\begin{array}{l}\text { It enables teaching with fun activities. via } \\
\text { educational games and animations }\end{array}$ & 2 & 9.5 & Student oriented - teacher is a guide. & 2 & 9.5 \\
\hline $\begin{array}{l}\text { Students can have education whenever or } \\
\text { wherever they want }\end{array}$ & 2 & 9.5 & There are many material types. & 1 & 4.8 \\
\hline $\begin{array}{l}\text { Students can get information from more } \\
\text { resources. }\end{array}$ & 2 & 9.5 & It enables easiness in assessment and evaluation. & 1 & 4.8 \\
\hline $\begin{array}{l}\text { As it pushes the students into research, it enables } \\
\text { their cognitive improvement. }\end{array}$ & 2 & 9.5 & It lessens teacher's labour burden & 1 & 4.8 \\
\hline $\begin{array}{l}\text { As it is student oriented, learning becomes } \\
\text { permanent. }\end{array}$ & 1 & 4.8 & Cost less & 1 & 4.8 \\
\hline $\begin{array}{l}\text { Even after they make a pause to school, they can } \\
\text { learn through computer }\end{array}$ & 1 & 4.8 & It helps to teach planned lesson. & 1 & 4.8 \\
\hline It enables effective and permanent learning. & 1 & 4.8 & Teacher leaves a bigger effect on students. & 1 & 4.8 \\
\hline They get computer & 1 & 4.8 & $\begin{array}{l}\text { Unobtainable expensive documents can bring into } \\
\text { classroom environment. }\end{array}$ & 1 & 4.8 \\
\hline $\begin{array}{l}\text { Abstract concepts become more } \\
\text { understandable. }\end{array}$ & 1 & 4.8 & $\begin{array}{l}\text { Teachers do not have any difficulty to gain } \\
\text { dominance over crowded classrooms. }\end{array}$ & 1 & 4.8 \\
\hline
\end{tabular}

When the views of pre-service teachers on benefits of CAE are examined, it is seen that they generally emphasize the benefits of CAE that emerged in writing field. At this point, it can be said that pre-service teachers have information about the benefits of CAE. The pre-service teachers draw attention to the fact that CAE especially addresses to more than one sense organs in terms of students, and this situation makes easier to understand (\%38.1), besides that CAE enables to repeat farther (\%28.6). When the views, stated as regarding of benefits in terms of teachers, are handled, nearly half of teachers state that CAE can embody the abstract concepts (\%52.4) and dangerous experiments can be done (\%42.9) in silico. As for, in some views, it seems that views to be stated in terms of benefits of DE (take education in different time and place, no time limit, etc.) are expressed by the pre-service teachers. 
Relating to the benefits of CAE, which are also stated in the body of literature, all those remarks stated suggest that pre-service teachers have a notable accumulation. As revealed in the former finding, they have the goods enough about the benefits of CAE even though the fact that pre-service teachers don't have an exact idea about what kind of learning-teaching process CAE is.

In research, pre-service teachers are demanded that they explain common formats used in CAE by giving examples. The formats which are stated most by pre-service teachers are given in the Table 4 with their frequencies and percentages.

Table 4. Pre-Service Teachers' Views Relating to Common Formats that are used in CAE

\begin{tabular}{ll}
\hline Expressed View & f \\
\hline Educational games (S1, S3, S4, S7, S11, S13, S14, S15, S16, S19, S20) & 11 \\
Simulations (S2, S3, S5, S6, S7, S8, S13, S15, S18, S21) & 52.4 \\
Animations (S1, S2, S4, S5, S6, S13, S14, S16, S18) & 47.6 \\
Tests (S11, S19) & 42.9 \\
Web-Based Training (S9) & 2 \\
Hypermedia (S8) & 10.5 \\
Instructional programmes (S13) & 4.8 \\
Explanatory, instructional, hypothesis models (S17) & 4.8 \\
Peer to peer interaction (S20) & 1 \\
\hline
\end{tabular}

When analyzing the pre-service teachers' responses about common formats in CAE, it is seen that pre-service teachers especially express "educational games" (\%52.4), "simulation" (\%47.6) and "animation" (\%42.9) formats in education literature. In addition to this, it is seen that a very small number of other formats in education literature are expressed. Pre-service teachers have expressed different views showing that they have knowledge about common formats used in CAE. For example, S2 has stated a view about simulations and animations as following: "Simulations are used to put the training about a subject into practice. There is no term of danger. Education can be provided with a low cost. Animations also allow students to acquire knowledge permanently after explaining a subject with moving images. A science teacher can reinforce the topic by showing the reaction of the elements with each other using an animation after explaining chemical reactions." S3 has stated a view about educational games as: "Lessons are made enjoyable with games. For example; animals and the classes of animals are given and learners are asked to place these animals in the class they belong to. Learners are given feedback in the game whether they are right or not." S12, "Common formats used in CAE are the closeness to the real life and can be updated. The proximity to the real life means that it includes sections of our daily life, is written in a language that people can understand and should be in harmony with the person's age and the environment where he/she lives in. Being updated should try to reach its goal by keeping pace with evolving technology and renewing itself" by reporting view in this way it tried to explain how these formats should be. The pre-service teachers participated in the study know at least one of the common formats used in CAE.

As a part of the research, the teachers were asked how they can evaluate an educational software prepared on computer, their views were gathered in five sub-categories, and the results were given with frequencies and percentages in Table 5. 
Table 5. Pre-Service Teachers' Evaluation Criteria of Educational Software

\begin{tabular}{|c|c|c|}
\hline \multicolumn{3}{|l|}{ Category 1: Educational Properties } \\
\hline Expressed View & $\mathrm{f}$ & $\%$ \\
\hline Appropriateness to target group (S2, S3, S4, S5, S6, S7, S10, S12, S14, S15, S17, S18, S19, S21) & 14 & 66.6 \\
\hline Appropriateness to purpose (S2, S3, S4, S6, S7, S14, S15, S17, S19, S20) & 10 & 47.6 \\
\hline Giving feedback (S5, S11, S15, S18) & 4 & 19 \\
\hline Going from easy to difficult (S2, S19) & 2 & 9.5 \\
\hline Making a sensation in student (S3) & 1 & 4.8 \\
\hline Activating student (S4) & 1 & 4.8 \\
\hline Giving opportunity to repeat (S7) & 1 & 4.8 \\
\hline Being appropriate to educational design models (S17) & 1 & 4.8 \\
\hline \multicolumn{3}{|l|}{ Category 2: Graphic Design Properties } \\
\hline Expressed View & $\mathrm{f}$ & $\%$ \\
\hline Being clear, comprehensible, remarkable (S3, S4, S7, S12, S13, S15, S18, S19, S20) & 9 & 42.9 \\
\hline Usableness $(\mathrm{S} 1, \mathrm{~S} 4)$ & 2 & 9.5 \\
\hline Coherence (S14, S17) & 2 & 9.5 \\
\hline Ranking buttons (S2) & 1 & 4.8 \\
\hline \multicolumn{3}{|l|}{ Category 3: Multimedia Properties } \\
\hline Expressed View & $\mathrm{f}$ & $\%$ \\
\hline Appealing to different senses (S5, S12, S20) & 3 & 14.3 \\
\hline Being able to search $(\mathrm{S} 2, \mathrm{~S} 18)$ & 2 & 9.5 \\
\hline \multicolumn{3}{|l|}{ Category 4: Content } \\
\hline Expressed View & $\mathrm{f}$ & $\%$ \\
\hline Containing factors like animation, game, etc.(S4, S7, S18, S21) & 4 & 19 \\
\hline Reflecting field contents completely (S1, S10, S19, S20) & 4 & 19 \\
\hline Currency $(\mathrm{S} 1, \mathrm{~S} 7, \mathrm{~S} 12)$ & 3 & 14.3 \\
\hline Little information- core information (S4, S12) & 2 & 9.5 \\
\hline Accuracy (S1) & 1 & 4.8 \\
\hline Verifiability (S1) & 1 & 4.8 \\
\hline Validity (S1) & 1 & 4.8 \\
\hline \multicolumn{3}{|l|}{ Category 5: Configuration and usage } \\
\hline Expressed View & $\mathrm{f}$ & $\%$ \\
\hline Relevant cost (S3, S4, S6, S19) & 4 & 19 \\
\hline Technical support (S3, S4, S6) & 3 & 14.3 \\
\hline Being executable easily (S5) & 1 & 4.8 \\
\hline Accessibility (S4) & 1 & 4.8 \\
\hline Having easy installation (S10) & 1 & 4.8 \\
\hline
\end{tabular}

When examined views of pre-service teachers in Table 5, it is observed that different views were asserted about the assessment of educational software. Pre-service teachers especially expressed the view about from educational properties of software to target group (\%66.6) and the suitability to the purpose (\%47.6). In this regard S2: "It has been reported that educational software should appeal to a particular target group, be purposeful, go from easy to difficult topics, appeal to the visual but shouldn't fatigue the eye more, should be able to do research to find a subject and the buttons should be take place order to enable us to go forward and back." The view of being the education software clear, understandable and appealing in terms of visual design features was voiced intensively by the pre-service teachers. (\%42.9). On the issue S12; "It has been reported that the educational software that we prepared should be clear, short and understandable, they should appeal to all walks of people and the visual contents attracting the people's attention should take place." In terms of content, four pre-service teachers (\%19) stated that educational software should include elements of animation, game etc., however four pre-service teachers (\%19) reported the view that this software should reflect the content of the software fully. In that topic, S20 reported that "Let's say we teach material and energy issues with educational software. Since used software will teach subject like a teacher, I think it should take place here all the contents of the software." Views on the installation and size of usage on educational software were also expressed by the pre-service teachers. Pre-service teachers especially emphasized the cost of software (\%19) and the technical support (\%14.3) that will be given for software. In that topic, S3 said that "It should be addressed to the needs, financially appropriate; provide technical and hardware support."

Considering the statements of evaluation criteria about educational software that were prepared on computer by pre-service teachers, it is seen that they expressed the criteria of body literature in terms of evaluation on educational software. Although not all the criteria were presented by taken the views of each pre-service teacher, many evaluations were reached to the criteria at the end of the content analysis. At this point, it shows that; also the views of pre-service teachers that are submitted by the scope of this question create a meaningful evaluation framework for education software. 


\subsection{The Views about Hypermedia Use}

In the research, the pre-service teachers are asked to examine the advantages of e-books in comparison with the materials as normal printed books to describe the views about the usage of hypermedia in education. The findings are collected in three sub-categories, given in Table 6 with their frequencies and percentages.

Table 6. Pre-Service Teachers' Views Related to the Advantages of E-Books over Published Books

\begin{tabular}{|c|c|c|}
\hline \multicolumn{3}{|l|}{ Category 1: Hypermedia Features in Education } \\
\hline Expressed View & $\mathrm{f}$ & $\%$ \\
\hline $\begin{array}{l}\text { Learning process supported via auditory, visual, graphic-based and video-based applications (S1, S2, S3, S4, S5, S6, } \\
\text { S7, S9, S10, S11) }\end{array}$ & 10 & 47.6 \\
\hline The audio files, images and animations applied; raising attention and motivation. (S1, S2, S3, S4, S5, S6, S7, S8) & 8 & 38.1 \\
\hline Ease of access to information. (S2, S3, S4, S5, S7, S8, S10, S21) & 8 & 38.1 \\
\hline Easier to keep information safe. $(\mathrm{S} 2, \mathrm{~S} 8)$ & 2 & 9.5 \\
\hline Shorter learning time. $(\mathrm{S} 3, \mathrm{~S} 5)$ & 2 & 9.5 \\
\hline More fun. (S7) & 1 & 4.8 \\
\hline Upgradable constantly. (S9) & 1 & 4.8 \\
\hline \multicolumn{3}{|l|}{ Category 2: Ease of Use } \\
\hline Expressed View & f & $\%$ \\
\hline Difficulty in carrying and getting access to published material. (S10, S13, S15, S18, S20) & 5 & 23.8 \\
\hline Less space occupied. (S11, S12, S13, S16, S21) & 5 & 23.8 \\
\hline \multicolumn{3}{|l|}{ Category 3: Economy } \\
\hline Expressed View & $\mathrm{f}$ & $\%$ \\
\hline Cost-effective. (S15, S17, S19, S20, S21) & 5 & 23.8 \\
\hline Savings in material. (S17, S18) & 1 & 4.8 \\
\hline
\end{tabular}

In Table 6, when the views of pre-service teachers about positive sides of e-books considering printed books are examined, it is seen that pre-service teachers mention about the positive sides of e-books especially the learning is consolidated when they practice with sound, image, graphic, video (\%47.6), the usage of settings as sound, image, animation increases the attention and motivation (\%38.1), and it obtains the easiness of reaching to knowledge (\%38.1). They mention about the positive sides of e-books as S3; "it supplies the permanence of knowledge in the mention with its sound, video, images, experiments, graphics, schemas and video. The knowledge can be integrated in the mention more easily via sound, image, video and text." S4; "the sound, image, video and text are all together in the e-books. So, it takes attention of the student and helps them to learn more effectively.", and S7; "There is only picture in addition to text in printed books. This can be abstract for students. There can be elements like animation, video in e-books, formed using hypermedia. It helps us to comprehend the subject better."

Some of the pre-service teachers have presented their views about the ease of use of e-books. For instance, S10; “... We can use them on phones and tablets with internet whenever and wherever we want, which we carry continuously. It is very difficult to carry those printed books but we can carry many e-books with these equipment" and it is also expressed by S13 that "when compared to printed books, e-books are replaced less, reachable when required." The other thing the pre-service teachers mention about the positive sides of the e-books is that they are advantageous economically. In this regard, they have expressed their views that S19; “... As many books as you want can be put into the tablets. When you want to see a word mentioned in the book or need to learn the meaning of the word, you can easily do that. Also, they cost less." Apart from those, there are more views like the contribution to the protection of the nature (S18), any type of information can be reached because of the multimedia (S17).

When the thoughts of the pre-service teachers have examined, it has been observed that the ones with the high academic achievement focus on the educational hypermedia features of e-books rather than the ones with lower academic achievement give importance to the ease of use and affordability.

\subsection{The Views about $D E$}

Within the scope of the searching views about the DE, as another question, the pre-service teachers have been required to examine why the popularity of DE has increased. The reasons expressed most by the pre-service teachers are shown on Table 7 with frequency and percentage. 
Table 7. Pre-Service Teachers' Views Related to the Reasons of DE's Popularity

\begin{tabular}{|c|c|c|}
\hline Expressed View & $\mathrm{f}$ & $\%$ \\
\hline Free from time and space. (S1, S3, S4, S5, S6, S7, S8, S10, S11, S12, S13, S14, S15, S16, S18, S19, S20) & 17 & 81 \\
\hline $\begin{array}{l}\text { Opportunity for students to compensate for their absences of several excuses. (S1, S2, S5, S7, S8, S10, S11, S12, } \\
\text { S13, S15, S16, S18, S19, S21) }\end{array}$ & 14 & 66.6 \\
\hline Allowing students to revise at choice. (S3, S4, S5, S8, S12, S13, S15, S17, S20) & 9 & 42.9 \\
\hline Allowing students of different backgrounds and cultures to interact. (S2, S6, S7, S11, S15, S17, S18, S20) & 8 & 38.1 \\
\hline Low-cost. (S4, S7, S9, S12, S15, S16, S21) & 7 & 33.3 \\
\hline Equal opportunities in education. (S2, S4, S6, S14, S17, S21) & 6 & 28.6 \\
\hline Reaching to large masses. (S5, S6, S7, S13, S14) & 5 & 23.8 \\
\hline Supporting life-long learning. (S2, S8, S12, S13, S19) & 5 & 23.8 \\
\hline Allowing people from different countries to exchange information. (S4, S6, S8, S12, S16) & 5 & 23.8 \\
\hline Allowing people of every age to get educated. (S5, S9, S13, S15, S19) & 5 & 23.8 \\
\hline Student-based. $(\mathrm{S} 4, \mathrm{~S} 9)$ & 2 & 9.5 \\
\hline
\end{tabular}

When Table 7 examined, it is observed that pre-service teachers highly emphasis (\%81) being independent from time and place of DE. In addition to this, it is also stated by the pre-service teachers that DE contribute to those who have not received formal education because of any handicap (\%66.6). DE offers repetition opportunity to student at choice has been mentioned by pre-service teachers (\%42.9). With regard to this topic S8 said that "Distance Education...is a useful system for students who cannot continue courses or who have disabilities. Since there is no time and place requirements students is able to listen any subjects they want whenever they want again and again. They may come back to subject they have not understand. ..” This view is often referred by different pre-service teachers. Pre-service teachers have also uttered such views as DE provides interaction between people from different cultures (\%38.1), it has low cost (\%33.3), it ensures the equality of opportunity in education (\%28.6), it addresses to large masses of people (\%23.8), it supports the lifelong learning (\%23.8), it provides communication between people different countries (\%23.8), it provides education for people from any age-group (\%23.8) and it is student-centered (\%9.5). For example, S17 has delivered a view in the way that "distance education prominently gives students equality of opportunity and facility. It helps students and teachers to join the education system at different times and different places. It provides students with education more comfortably without pressure whenever and wherever they want. Concerning the fact that distance education enhances the interaction between different cultures, has low cost and addresses to large masses of people". Considering the reasons pre-service teachers have mentioned regarding the popularity of DE it can be seen that they have right information about it. A great number of positive aspects, also mentioned in literature, have been highly emphasized by the pre-service teachers.

\subsection{The Views about Database Management}

Pre-service teachers who took part in the research were asked to examine the reasons of more effective usage of database management systems instead of keeping printed data, the reasons which were mentioned most by the pre-service teachers were shown with the frequency and the percentages on Table 8 .

Table 8. Pre-Service Teachers' Views Related to the Reasons of Effectiveness in Database Management Systems

\begin{tabular}{ll}
\hline Expressed View & f \\
\hline Ease of access to data on demand. (S1, S2, S3, S4, S5, S6, S7, S8, S9, S10, S11, S12, S14, S15, S17, S18, S20) & 17 \\
Better safety (of backup, authorised user etc.) (S1, S3, S4, S6, S7, S9, S11, S13, S16, S19) & 81 \\
Enabling to add and edit data. (S2, S4, S5, S7, S8, S12, S21) & 47.6 \\
Upgradable. (S1, S8, S9, S13, S16, S20) & 33.3 \\
More practical. (S9, S10, S12, S16, S18) & 28.6 \\
Savings in time. (S4, S7, S9, S13, S19) & 23.8 \\
Ease of data storage. (S2, S5, S11, S17, S21) & 5 \\
Usage in university entrance system. (S10, S12, S14, S15, S21) & 5 \\
Chance to delete data. (S2, S4, S5, S8) & 23.8 \\
Better cost-effectiveness compared to published material. (S7, S16, S18, S20) & 23.8 \\
Occupying less space compared to published material. (S9, S14, S19, S21) & 4 \\
Storage provided via the net. (S5, S7, S14) & 4 \\
Enabling product and service procurement. (S8, S17, S21) & 4 \\
Confirmed and ready to get confirmed. (S1, S4, S5) & 19 \\
Chance to buy online. (S19, S20) & 3 \\
Chance to form reports and forms (S3, S9) & 19 \\
\hline
\end{tabular}

In Table 8, the great majority of the pre-service teachers register about the ability of database management systems easy access to data (\%81). Again nearly half of the pre-service teachers mention the reliability of these systems (\%47.6). The data entry and regulation are easy to database management system (\%33.3) and the updating of the system is among the views expressed by pre-service teachers (\%28.6). About the cause of effectiveness of database management system S3 expressed that "the database is used effectively because it allows the storage and use of the information, allows to make 
flight reservation, it is used for trading products and service, it is used in university entrance system, it gives a change to find a job and provides shopping opportunities on the net. For example, in automation system the data of us is filled by teachers, we can get our transcript in the form of reported from the registrar's office" and S7; "in terms of reliability database has got benefits. For example, you can copy data whether they are deleted or damaged. Saving time is possible through the data base. If I give an example when we apply for university exam we take photo. These photos are used when registering university." Saying these they emphasize the database of current benefits. In relation to processing, arrangement, and deletion dimension of data of database management systems S12; "Data is all the raw information. Text, video, sound, history, Money and image can be given as a sample. Data can be processed, arranged and deleted. Organizing by the data manager data can appear as a new data. For obtaining new data and presenting to the learners data should be stored in computers by processing..." gave a view.

\section{Discussion}

It is requested that sample usage is firstly to be given to pre-service teachers that could be CAE or not. Although pre-service teachers stated that lecturing on a subject via slides could be a CAE implementation, they indicated that PowerPoint presentations that are prepared to narrate could not be a CAE implementation (Table 2). Ottenbreit-Leftwich et al. (2012) have carried out a study in order to describe what kind of content teacher education programmes should contain to the extent that learning and instruction process support technology and how pre-service teachers should be prepared to be efficient in using technology with the teachers working in sector and the academicians who train teachers. They have made out that especially academicians use technology for their individual productivity and presenting information in this study. They have stated that teachers go on this attitude because they also see the use of this technology in their undergraduate education. Many academicians in institutions that train teachers in our country also carry out their lessons using presentation materials. In this regard, we confront a situation that almost half of the teacher candidates are expected to describe carrying out lessons with presentations prepared in computers as CAE. In addition this, some of the pre-service teachers have stated that FATIH Project, Instruction CDs, e-books, tablets, hypermedia and the webpage of Niğde University could be defined as CAE that utters an systematic and programmed instruction. In this respect, it is understood that pre-service teachers are not able to acquire sufficient information about what type of process could be CAE in both their technology-oriented lessons and implementations carried out by their academicians. For this reason, pre-service teachers are to be informed in their intraclass implementations and lessons what CAE is about and be involved the process of self-instruction about CAE when they start to instruct.

When the views of pre-service teachers on the benefits of CAE in terms of students and teachers are analysed, positive qualities of CAE were stressed by pre-service teachers such as that it embodies the abstract terms with the components like illustration and sound, facilitates comprehension because of addressing five senses, makes dangerous experiments innocuous, ensures the recap possibility, ensures time saving, it is student oriented, increases the motivation, allows to advance in individual rates (Table 3). These ideas expressed by pre-service teachers amongst the benefits handled in department writing of CAE (Çelik, 2009; Erişen \& Çeliköz, 2011; İşman, 2011a; Seferoğlu, 2007; Şentürk, 2009; Tüfekçi \& Köse, 2014; Uşun, 2000; Yalın, 2014; Yanpar Yelken, 2014). In addition many research findings related to CAE was considered beneficial by pre-service teachers is matter of issue (B. Arslan, 2003; Keşan \& Kaya, 2007; Kutluca \& Birgin, 2007; Seferoğlu, Akbıyık, \& Bulut, 2008; Yavuz \& Coşkun, 2008; Yenilmez, 2009; Yenilmez \& Gökmen, 2007). On the scope of BIT, by depending on frequent usage of especially computer in education, it was seen as a good improvement that several benefits of CAE which take place in department writing of it even if not all of them had been expressed by pre-service teachers.

In the research, the pre-service teachers have been demanded to explain the common formats being used in CAE by exemplifying them in order to figure out more profoundly how CAE was understood by them. The pre-service teachers have stated educational games, simulations and animations at the highest rates (Table 4). It is thought that they have expressed like this because of the fact that the pre-service teachers have been using especially these formats in their teaching presentations in the micro-teaching applications which they have carried out aiming for especially science subjects in their undergraduate education. Gülçiçek and Güneş have pointed out the teaching of science lessons with models and modelling in their essay they have written in 2004. According to the writers, the most important goal of teaching science is to provide the students with understanding the concepts correctly and applying them. Especially, making the abstract science notions concrete has a great importance. At this point, they can make use of animations and simulations. In teaching science, educational computer games are also one of the mostly used formats. Coşkun, Akarsu and Kariper (2012) have concluded that educational games including science stories have increased the students' academic success in their quasi-experimental study which they have carried out with 30 7th grade students in the primary school. In the study, Bakar, Tüzün and Çağlltay (2008) have given view about the necessity for the fact that the educational games should be preferred often in science courses. There are a number of different studies similar to those ones based on this field (Aycan, Arı, Türkoğuz, Sezer, \& Kaynar, 2002; Daşdemir, 2006; Daşdemir \& Doymuş, 2012; 
Genç, 2013; Okur \& Ünal, 2010). The pre-service teachers are expected to use those CAE formats mentioned above in their not only undergraduate education but also in classroom tasks or off tasks especially for the aim of making the science courses concrete.

Pre-service teachers within the context of a research have been asked how to evaluate an educational programme prepared on computer based. The responds of them are categorized as the use and the setting with content, educational features, visual design features, multimedia features. The pre-service teachers indicate that it should be paid attention to these criterias such as at suitable cost and giving technical support at the highest rate in terms of educational features; to be suitable for the aim and the target group in terms of visual design features; to be clear, understandable and remarkable in terms of multimedia features; to be sentimental in terms of content; including some factors such as games, animations and etc. in terms of setting and use.(Table 5).These views expressed by the pre-service teachers and the categories related to the evaluation criterias obtained from these views have parallels with the category which take part in "The Rating Scale of Educational Software" on which Kara (2007) has made a reliability and validity study and developed and with the items in each category. Kara (2007) has divided this educational software which he developed in his scale into five categories as 'content', 'easiness of use', 'technical features' and 'personal views'. In another study, Secken and Kunduz (2013) have applied this developed scale on the candidates of Chemistry Teachers intending to evaluate the educational software and have reached the result of having an important effect on understanding the subjects of this software. In another studies related to evaluate the educational software, there are also similar items expressed by the pre-service teachers (Ateş, 2011; Ş. Kaya, Kurfallı, Avşar, \&Aksüt, 2007). At this point it is said that the pre-service teachers have a general evaluation view on evaluating the educational software.

In the research, the use of hypermedia by pre-service teachers has been tackled as a different sub-dimension. In order to determine the views towards the hypermedia use, pre-service teachers were asked to express the advantages of e-books compared to books in traditionally printed material. Findings have showed that the views of the pre-service teachers were gathered in three different categories: 'characteristics of hypermedia in education', 'ease of use' and 'economy' (Table 6). Pre-service teachers delivered their views in a way that e-books could reinforce the learning through the elements such as sound, picture, graphics, animation and video with regard to 'the characteristics of hypermedia in education'. They also stated that these elements would improve students' attention and motivation. Furthermore, they suggested that e-books facilitated the access to information and that information could be stored easier by means of e-books. In a similar study carried out in cooperation with science teachers by Daşdemir, Cengiz, Uzoğlu and Bozdoğan (2012), it was concluded as the advantages presented in the content using tablet computers by teachers that they could make science and technology classes more entertaining through visuals and animations and enhance the interest of students' in science and technology subject. In another study carried out with primary school teachers by Duran and Ertuğrul (2012), it was assessed as an advantage by the teachers that e-class books would support course content by means of visuals and sounds, allow for interactive education processes, enable education without books to be taken into action, appear to be more reasonable and inviting and prevent paper wastage.

In the expressed views within the scope of the advantages with regard to "ease of use" of e-books, pre-service teachers have mentioned about the difficulties of carrying printed materials and accessing them. In this point, they are emphasized that they take a small space, they are easy to carry, and they have an ease of accessing the contents. In another work, we can reach the same conclusions as we have mentioned above. About the "economy" as the last category, pre-service teachers have thought that e-books have relevant costs and they let us derive a profit from the material. Also in 2012, Soydan have mentioned about the relevant costs of e-books and that they are ecologist products by preventing woodchopping in his essay. Similarly, it is seen that Aydemir, Küçük, and Karaman (2012) have pointed that in a study made with 34 post graduate students educating by distance learning with their tablet computers, they have used the contents of e-books effectively in their computers and that these contents of e-books provide them benefits about the time and the cost. So, it can be seen that the views mentioned by the pre-service teachers participated the study about the contents of e-books which includes especially hypermedia components is reciprocated in other studies of the field. Pre-service teachers' notices that e-books are more useful than the books as printed materials.

In the study, pre-service teachers are demanded to examine the causes of being popular of DE as a different aspect. While they are arranging the causes of this popularity, they have mentioned about being independent of time and place, facilitating education to the people who aren't able to participate to formal education because of any reason, providing repetition and reinforcement, carrying out the cultural interaction, providing low costs and equal opportunities of education, supporting lifelong learning, addressing to a mass of people, etc. (Table 7). These views mentioned by the preserving teachers about the benefits of DE are also mentioned in a lot of sources in the field (Arat \& Bakan, 2011; Esgin \& Saraç, 2015; İşman, 2011a; 2011b; Kandemir, 2014; Seferoğlu, 2007; Yanpar Yelken, 2014; Yılmaz \& Güven, 2015).

In the research, finally, it is expected from pre-service teachers to explain the reason why they use the database 
management systems instead of keeping printed data. Pre-service teachers rank some advantages of this system such as facilitating the access of data, backing up, defining authorised user and some positive sides such as addition, preparation and updating of data easily. Some pre-service teachers who are at medium or lower level emphasize that database management systems provide product and service procurement and these systems enable doing the online shopping easily. According to Bayraç (2003), computer and telecommunication technologies and specially database management systems underlie e-commerce. Provided that these technologies by means of being transported internet environment, global e-commerce is carried out. The reasons ranked by pre-service teachers show that they are informed of the positive sides of database management systems themselves.

According to the results of research, it is understood that Science Pre-service Teachers have general information which finds an expression in literature in terms of BIT's educational dimension. However, there is only a matter of assessment in this conducted research. Hence, the research does not contain information about how pre-service teachers can use BIT in their lesson activities. It is suggested that other applied studies to reveal science pre-service teachers' usage of BIT during education periods should be conducted.

\section{References}

Alkan, C. (1995). Eğitim teknolojisine giriş: Disiplin, Süreç, Ürün [Introduction to educational technology: Discipline, process, product]. Ankara, Turkey: Önder Matbaacılık.

Anderson, S. E., \& Maninger, R. M. (2007). Preservice teachers' abilities, beliefs, and intentions regarding technology integration. Journal of Educational Computing Research, 37(2), 151-172. http://dx.doi.org/10.2190/H1M8-562W-18J1-634P

Arat, T., \& Bakan, Ö. (2011). Uzaktan eğitim ve uygulamaları [Distance education and it's applications]. Selçuk Üniversitesi Sosyal Bilimler MYO Dergisi, 14(1-2), 363-374.

Arıkan, Y. D. (2006). Web destekli etkin öğrenme uygulamalarının öğretmen adaylarının derse yönelik tutumları üzerindeki etkileri [The effects of web-supported active learning activities on teacher trainees' attitudes towards course]. Ege Eğitim Dergisi, 7(1), 23-41.

Arslan, A. (2006). Bilgisayar destekli eğitim yapmaya ilişkin tutum ölçeği [The attitude scale toward making computer supported education]. Yüzüncü Yıl Üniversitesi Eğitim Fakültesi Dergisi, 3(2), 24-33.

Arslan, B. (2003). Bilgisayar destekli eğitime tabi tutulan ortaöğretim öğrencileriyle bu süreçte eğitici olarak rol alan öğretmenlerin BDE'e ilişkin görüşleri. [The views of teachers who plays educator role and students who are taught with computer aided education about this process]. The Turkish Online Journal of Educational Technology, 2(4), 67-75.

Ateş, A. (2011). Eğitsel yazılım değerlendirme ölçeği: geçerlik ve güvenirlik çalışması [Educational software evaluation scale: validity and reliability study]. Eğitim Teknolojileri Araştırmaları Dergisi, 2(1).

Aycan, Ş., Arı, E., Türkoğuz, S., Sezer, H., \& Kaynar, Ü. (2002). Fen ve fizik öğretiminde bilgisayar destekli simülasyon tekniğinin öğrenci başarısına etkisi: Yeryüzünde hareket örneği [The effect of computer aided instruction with simulation on student achievement]. Atatürk Eğitim Fakültesi Ĕ̆itim Bilimleri Dergisi, 15, 57-70.

Aydemir, M., Küçük, S., \& Karaman, S. (2012). Examining students'views using tablet PC in distance education. Journal of Research in Education and Teaching, 1(4), 153-159.

Bakar, A., Tüzün, H., \& Çağıltay, K. (2008). Students' opinions of educational computer game utilization: a social studies course case. H. U. Journal of Education, 35, 27-37.

Başaran, M. (2005). Sınıf öğretmeni adaylarının bilgi okuryazarlıklarının değerlendirilmesi [Evaluation of preservice primary school teachers' information literacy]. Gazi Eğitim Fakültesi Dergisi, 25(3), 163-177.

Bayraç, H. N. (2003). Yeni ekonomi'nin toplumsal, ekonomik ve teknolojik boyutları [Social, economic and technological dimensions of new economy]. Eskişehir Osmangazi Üniversitesi Sosyal Bilimler Dergisi, 4(1), 41-62.

Board, N. S. (2002). Science \& engineering indicators. National Science Foundation Arlington, 1, 34-51.

Büyüköztürk, Ş., Çakmak, K. E., Akgün, Ö. E., Karadeniz, Ş., \& Demirel, F. (2011). Bilimsel araştırma yöntemleri [Research methods] (8. ed.). Ankara, Turkey: Pegem Akademi.

Çelik, L. (2009). Bilgisayar destekli öğretim ve sanal gerçeklik uygulamaları [Computer assisted instruction and virtual reality applications]. In E. Altun (Ed.), Bilgisayar ve ögretim teknolojileri eğitimi bölümleri için özel ögretim yöntemleri I-II [Special teaching methods for computer education and instructional technology departments I and II] (Vol. 6, pp. 169-190). Ankara, Turkey: Pegem Akademi. 
Chen, R. (2010). Investigating models for preservice teachers' use of technology to support student-centered learning. Computers \& Education, 55(1), 32-42. http://dx.doi.org/10.1016/j.compedu.2009.11.015

Christensen, R. (2002). Effects of technology integration education on the attitudes of teachers and students. Journal of Research on technology in Education, 34(4), 411-433. http://dx.doi.org/10.1080/15391523.2002.10782359

Collier, K., Paula, F., \& Goff, R. (1971). Colleges of Education Learning Programmes: A proposal (Working Paper No.5). Washington, DC: Commission on Instructional Technology.

Coşkun, H., Akarsu, B., \& Kariper, İ. A. (2012). Bilim öyküleri içeren eğitsel oyunların fen ve teknoloji dersindeki ögrencilerin akademik başarılarına etkisi [The effects of educational games based on science stories on students' academic achievements in science and technology classroom]. Ahi Evran Üniversitesi Kırşehir Eğitim Fakültesi Dergisi, 13(1), 93-109.

Daşdemir, İ. (2006). Animasyon kullanımının ilkögretim fen bilgisi dersinde akademik başarlya ve kalıcılı̆ga olan etkisi [The effect of use animation on students' academic achivements and retentions in primary science course]. (Master thesis), Atatürk University, Graduate School Of Natural And Applied Sciences, Erzurum, Turkey.

Daşdemir, İ., \& Doymuş, K. (2012). Fen ve teknoloji dersinde animasyon kullanımının öğrencilerin akademik başarılarına, öğrenilen bilgilerin kalıcılığına ve bilimsel süreç becerilerine etkisi [The effect of using animation on primary science and technology course students' academic achivement, retention of knowledge and scientific process skills]. Pegem Ĕ̈itim ve Ö̆gretim Dergisi, 2(3), 33-42.

Daşdemir, İ., Cengiz, E., Uzoğlu, M., \& Bozdoğan, A. E. (2012). Examination of science teachers' opinions related to tablet pcs using in science and technology courses. Mustafa Kemal University Journal of Social Sciences Institute, 9(20), 495-511.

Duran, E., \& Ertuğrul, B. (2012). İlköğretim sınıf öğretmenlerinin elektronik ders kitaplarına yönelik görüşleri [Primary school teachers' views about electronic textbooks]. Türk Eğitim Bilimleri Dergisi, 10(2), 347-365.

Ekiz, D. (2003). Eğitimde araştırma yöntem ve metodlarına giriş: Nitel, nicel ve eleştirel kuram metodolojileri [Introduction to research methods and training methods: Qualitative, quantitative and critical theory methodologies]. Ankara, Turkey: Anı Yayınc1lik.

Erdemir, N., Bakırc1, H., \& Eyduran, E. (2009). Determination of teachers in educational technology ability to use self-confidence. Journal of Turkish Science Education, 6(3), 99-108.

Erişen, Y., \& Çeliköz, N. (2011). Eğitimde bilgisayar kullanımı [The use of computers in education]. In Ö. Demirel \& E. Altun (Eds.), Öğretim teknolojileri ve materyal tasarımı [Instructional technology and material design] (5. ed., Vol. 5, pp. 113-146). Ankara, Turkey: Pegem Akademi.

Esgin, E., \& Saraç, A. (2015). The effects of online and in-class groupworks on academic achievement, attitude and willingness for social interaction. SDU International Journal of Educational Studies, 2(1), 38-52.

Fisher, M. (2000). Computer skills of initial teacher education students. Journal of Information Techology for Teacher Education, 9(1), 109-123. http://dx.doi.org/10.1080/14759390000200075

Funkhouser, B. J., \& Mouza, C. (2013). Drawing on technology: An investigation of preservice teacher beliefs in the context of an introductory educational technology course. Computers \& Education, 62, 271-285. http://dx.doi.org/10.1016/j.compedu.2012.11.005

Genç, M. (2013). Views of prospective teachers about computer animations: Cell and tissues sample. Mersin University Journal of the Faculty of Education, 9(2), 288-300.

Gülçiçek, Ç., \& Güneş, B. (2004). Concretizing of concepts in science teaching: modelling strategy, computer simulations and analogies. Education and Science, 29(134), 36-48.

Güven, İ. (2014). Examination of information literacy and media literacy levels of science and technology teacher candidates. Electronic Turkish Studies, 9(2), 787-800. http://dx.doi.org/10.7827/TurkishStudies.6395

Higher Education Council (2007a). Ĕ̈itim fakülteleri öğretmen yetişstirme lisans programları [Teacher training graduate programs of education faculties]. Retrieved from

https://www.yok.gov.tr/documents/10279/30217/E\%C4\%9E\%C4\%B0T\%C4\%B0M+FAK\%C3\%9CLTES\%C4\%B 0\%20\%C3\%96\%C4\%9ERETMEN+YET\%C4\%B0\%C5\%9ET\%C4\%B0RME+L\%C4\%B0SANS+PROGRAMLA RI.pdf/054dfc9e-a753-42e6-a8ad-674180d6e382 , (26 October 2015).

Higher Education Council (2007b). Fen bilgisi lisans programı ders içerikleri Course contents of Science education graduate program. Retrieved from 
http://www.yok.gov.tr/documents/10279/49665/fen_bilgisi/f385bc78-22df-497d-bfca-7aee80c75c22, (26 October 2015).

İşman, A. (2011a). Öğretim teknolojileri ve materyal tasarımı [Instructional technology and material design] (4. ed.). Ankara, Turkey: Pegem Akademi.

İşman, A. (2011b). Uzaktan eğitim [Distance education] (4. ed.). Ankara, Turkey: Pegem Akademi.

Kandemir, O. (2014). Applications of distance education at the higher education level in turkey: opportunity equality in education and economic development. Electronic Turkish Studies, 9(5), 1155-1176. http://dx.doi.org/10.7827/TurkishStudies.6850

Kara, Y. (2007). Eğitim yazılımları değerlendirme ölçeği (EYDÖ): geçerlik ve güvenirlik çalışması [Educational software evaluation scale (ESES): Validity and reliability study]. Sakarya Üniversitesi Eğitim Fakültesi Dergisi, 14, 77-90.

Karaa, F. N., Aydın, F., Bahar, M., \& Yılmaz, Ş. (2014). Fen bilgisi öğretmen adaylarının teknolojiye ilişkin görüşleri [Pre-service science teachers' views about technology]. Abant İzzet Baysal Üniversitesi Eğitim Fakültesi Dergisi, 14(1), 118-139. http://dx.doi.org/10.17240/aibuefd.2014.14.1-5000091505

Kaya, A., \& Kaya, B. (2014). Teacher candidates' perceptions of digital citizenship. International Journal of Human Sciences, 11(2), 346-361. http://dx.doi.org/10.14687/ijhs.v11i2.2917

Kaya, Ş., Kurfallı, H., Avşar, T., \& Aksüt, M. (2007). Ĕgitim yazılımlarının değerlendirilmesi [Evaluation of Educational Software]. Paper presented at the XVI. National Educational Sciences Congress, (05-07 September 2007), Tokat, Turkey.

Keşan, C., \& Kaya, D. (2007). Bilgisayar destekli temel matematik dersi öğretimine sınıf öğretmenliği öğrencilerin bakış açıları [The viewpoints of elementary education pre-service teachers about computer aided basic mathematic course teaching]. Bilim, Eğitim ve Düşünce Dergisi, 7(1). Retrieved from http://www.universite-toplum.org/text.php3?id=305 (10.11.2015).

Kim, C., Kim, M. K., Lee, C., Spector, J. M., \& DeMeester, K. (2013). Teacher beliefs and technology integration. Teaching and Teacher Education, 29, 76-85. http://dx.doi.org/10.1016/j.tate.2012.08.005

Kutluca, T., \& Birgin, O. (2007). Doğru denklemi konusunda geliştirilen bilgisayar destekli öğretim materyali hakkında matematik öğretmeni adaylarının görüşlerinin değerlendirilmesi [Evaluation of prospective mathematics teachers' views about computer assisted teaching material developed in the linear equation topic]. Gazi Eğitim Fakültesi Dergisi, 27(2), 81-97.

Levin, B. B. (1996). Using portfolios to fulfill ISTE/NCATE technology requirements for preservice teacher candidates. Journal of Computing in Teacher Education, 12(3), 13-20.

Manik, M. M., Qasim, M., \& Shareef, A. F. (2014, 05-07 February 2014). Embedding 21st century skills in pre-service teacher training: A Case Study from the Maldives. Paper presented at the Conference On Professional Development In Education (PDE2014), (05-07 February 2014), Widyatama University Indonesia, Open University Indonesia and Open University Malaysia. URL: http://2014.pdeconference.com/

Okur, N., \& Ünal, İ. (2010). Fen öğretiminde bilgisayar destekli öğretimin önemi [The importance of computer assisted instruction in science education]. Ĕgitim Teknolojileri Araştırma Dergisi (ETAD), 1(3), 1-12.

Önal, N., \& Çetin, O. (2014). Öğretmen adaylarının bilgi okuryazarlıklarının çeşitli değişkenler açısından incelenmesi [Examination of pre-service teachers' information literacy in terms of various variables]. Mehmet Akif Ersoy Üniversitesi Eğitim Fakültesi Dergisi, 29, 1-30.

Ottenbreit-Leftwich, A. T., Brush, T. A., Strycker, J., Gronseth, S., Roman, T., Abaci, S., . . Plucker, J. (2012). Preparation versus practice: How do teacher education programs and practicing teachers align in their use of technology to support teaching and learning? Computers \& Education, 59(2), 399-411. http://dx.doi.org/10.1016/j.compedu.2012.01.014

Retrieved from http://www.pegem.net/akademi/kongrebildiri_detay.aspx $? i d=4970$

Rodriguez, S. (1996). Preparing preservice teachers to use technology. TechTrends, 41(4), 18-22. http://dx.doi.org/10.1007/BF02813335

Ruggiero, D., \& Mong, C. (2013). Improving understanding of pre-service teacher experience with technology integration. International Journal of Multimedia \& Its Applications, 5(5), 1-15. http://dx.doi.org/10.5121/ijma.2013.5501 
Sadi, S., Şekerci, A. R., Kurban, B., Topu, F. B., Demirel, T., Tosun, C., . . Göktaş, Y. (2008). Öğretmen eğitiminde teknolojinin etkin kullanımı: Öğretim elemanları ve öğretmen adaylarının görüşleri [Effective technology use in teacher education: the views of faculty members and preservice teachers]. Bilişim teknolojileri dergisi, 1(3), 43-49.

Secken, N., \& Kunduz, N. (2013). An evaluation of the educational software about precipitation titrations. Procedia Social and Behavioral Sciences, 106, 387-393. http://dx.doi.org/10.1016/j.sbspro.2013.12.044

Seferoğlu, S. S. (2007). Öğretim teknolojileri ve materyal tasarımı [Instructional technology and material design] (4. ed.). Ankara, Turkey: Pegem Akademi.

Seferoğlu, S. S., Akbıyık, C., \& Bulut, M. (2008). İlköğretim öğretmenlerinin ve öğretmen adaylarının bilgisayarların öğrenme/öğretme sürecinde kullanımı ile ilgili görüşleri [Elementary school teachers' and teacher candidates' opinions about computer use in learning/teaching process]. H. U. Journal of Education, 35, 273-283.

Şentürk, A. (2009). Bilgisayarların öğretimdeki uygulamaları ve bilgisayar destekli öğretim [Computer practices in teaching and computer-aided teaching]. In M. Sarıtaş (Ed.), Öğretim teknolojileri ve materyal tasarımı [Instructional technology and material design] (2. ed., Vol. 6, pp. 125-135). Ankara, Turkey: Pegem Akademi.

Soydan, E. (2012). E-kitap teknolojisi ve basılı kitabın geleceği [E-book technology and the future of the printed book]. Journal of Life Sciences, 1(1), 389-399.

Teo, T., \& Noyes, J. (2014). Explaining the intention to use technology among pre-service teachers: a multi-group analysis of the Unified Theory of Acceptance and Use of Technology. Interactive Learning Environments, 22(1), 51-66. http://dx.doi.org/10.1080/10494820.2011.641674

Tüfekçi, A., \& Köse, U. (2014). Yazılım seçimi ve sınıf entegrasyonu [Software selection and class integration]. In H. Çakır \& S. Eryılmaz (Eds.), Ĕgitimciler için biliş̧im teknolojileri [ICT for educators] (Vol. 12, pp. 381-398). Ankara, Turkey: Pegem Akademi.

Türnüklü, A. (2000). Eğitimbilim araştırmalarında etkin olarak kullanılabilecek nitel bir araştırma tekniği: görüşme [A qualitative research technique that can be used effectively in pedagogy research: interview]. Kuram ve Uygulamada Ĕ̈itim Yönetimi Dergisi, 24, 543-559.

Türnüklü, A. (2001). Eğitim bilim alanında aynı araştırma sorusunu yanıtlamak için farklı araştırma tekniklerin birlikte kullanılmas1 [Using different research techniques for the same question in educational science]. Education and Science, 26(120), 8-13.

UNSPECIFIED (2001) European report on the quality of school education. Sixteen quality indicators. Report based on the work of the Working Committee on Quality Indicators. [EU Commission - Working Document]. Retrieved from http://aei.pitt.edu/42406/ (26 October 2015).

Uşun, S. (2000). Dünyada ve Türkiye'de bilgisayar destekli ögrretim [Computer assisted instruction in the world and Turkey]. Ankara, Turkey: Pegem A Yayıncilık.

Yalın, H. İ. (2014). Öğretim teknolojileri ve materyal tasarımı [Instructional technology and material design] (26. ed.). Ankara, Turkey: Nobel Akademik Yayınclık.

Yanpar, Y. T. (2014). Öğretim teknolojileri ve materyal tasarımı [Instructional technology and material design] (12. ed.). Ankara, Turkey: Anı Yayınc1lı.

Yavuz, S., \& Coşkun, E. A. (2008). Sınıf öğretmenliği öğrencilerinin eğitimde teknoloji kullanımına ilişkin tutum ve düşünceleri [Attitudes and perceptions of elementary teaching through the use of technology in education]. $H$. $U$. Journal of Education, 34, 276-286.

Yenilmez, K. (2009). Öğretmen adaylarının bilgisayar destekli matematik öğretimi dersine yönelik görüşleri [Teacher candidates' opinions about the computer aided mathematics instruction course]. Sosyal Bilimler Dergisi, 21, 207-220.

Yenilmez, K., \& Gökmen, R. (2007). Eğitim fakültesi ögrencilerinin bilgisayar destekli eğitime ilişskin düşünceleri [The opinions of education faculty students about computer aided education]. Paper presented at the 7th International Educational Technology Conference, (3-5 May 2007), North Cyprus: Near East University.

Yeung, A. S., Tay, E. G., Hui, C., Lin, H. L., \& Low, E. L. (2014). Pre-service teachers' motivation in using digital technology. Australian Journal of Teacher Education, 39(3), 135-153. http://dx.doi.org/10.14221/ajte.2014v39n3.1

Yıldırım, A., \& Şimşek, H. (2008). Sosyal bilimlerde nitel araştırma yöntemleri [Qualitative research methods in the social sciences] (7. ed.). Ankara, Turkey: Seçkin Yayıncilık. 
Yılmaz, G. K., \& Güven, B. (2015). Determining the teacher candidates' perceptions on distance education by metaphors. Turkish Journal of Computer and Mathematics Education (TURCOMAT), 6(2), $299-322$. http://dx.doi.org/10.16949/turcomat.75936

Yilmaz, M. (2007). Sınıf öğretmeni yetiştirmede teknoloji eğitimi [Instructional technology in training primary school teacher]. Gazi Ĕgitim Fakültesi Dergisi, 27(1), 155-167.

\section{$(\mathrm{cc}) \mathrm{BY}$}

This work is licensed under a Creative Commons Attribution 3.0 License. 